Article

\title{
Fatty Acid Profile of Cheese from Dairy Goats Fed a Diet Enriched with Castor, Sesame and Faveleira Vegetable Oils
}

\author{
Ertha Medeiros ${ }^{1}$, Rita Queiroga ${ }^{2}$, Maria Oliveira ${ }^{3}$, Ariosvaldo Medeiros ${ }^{4}$, Mayara Sabedot ${ }^{4}$, \\ Marco Bomfim ${ }^{5}$ and Marta Madruga ${ }^{1, *}$
}

1 Graduate Program in Science and Food Technology, Department of Foods Engineering, Technology Center, Federal University of Paraiba (PPGCTA/DEA/CT/UFPB ), Campus I, Joao Pessoa, Paraiba 58.059-900, Brazil; E-Mail: erthajanine@yahoo.com.br

2

Department of Nutrition, Center for Health Sciences, Federal University of Paraiba

(DN/CCS/UFPB), Campus I, Joao Pessoa, Paraiba 58.059-900, Brazil;

E-Mail: rcqueiroga@uol.com.br

3 Department of Nutrition, Federal University of Campina Grande, Cuité, Paraiba 58.175-000, Brazil;

E-Mail: elieidynutri@yahoo.com.br

4 Department of Animal Science, Agricultural Science Center, Federal University of Paraiba

(DZ/CCA/UFPB), Campus II, Areia, Paraiba 58.397-000, Brazil;

E-Mails: ariosvaldo.medeiros@gmail.com (A.M.); mayara_sabedot@hotmail.com (M.S.)

5 National Center for Goat and Sheep Research, Embrapa, Sobral, Ceara 62.011-970, Brazil;

E-Mail: marco.bomfim@embrapa.br

* Author to whom correspondence should be addressed; E-Mail: msmadruga@uol.com.br;

Tel: +55-83-3216-7473; Fax: +55-83-3216-7119.

Received: 18 November 2013; in revised form: 7 January 2014 / Accepted: 8 January 2014 /

Published: 15 January 2014

\begin{abstract}
The addition of vegetable oils to the diets of dairy goats is an alternative to supplemental feeding during the dry period and improves the lipid profile of milk and by-products. Cheeses were produced using milk from cross bred goats (Saanen $\times$ Alpina) fed diets enriched with $4 \%$ vegetable oil (faveleira, sesame or castor), the fatty acid profile of cheeses was studied. Supplementation with vegetable oils did not increase the total fat percentage of the cheese $(p \geq 0.05)$ but did increase the percentage of CLA isomers, longchain fatty acids (LCFA) and polyunsaturated fatty acids (PUFA); in addition, the index of desirable fatty acids (DFA - expressed as the sum of unsaturated fatty acids plus stearic acid) was increased for cheese made from milk from goats fed sesame or faveleira oil.
\end{abstract} Cheeses may have had increased percentages of cis-9,trans-11-CLA due to the 
supplementation of animal diets with vegetable oils rich in $\mathrm{C} 18: 2$, such as faveleira and sesame oils. The fatty acid profile of goat cheese did not change significantly in response to the use of castor oil. Thus, the addition of sesame and faveleira oils to goat diets positively altered the fatty acid profile, which improved the nutritional characteristics of the fat present in goat cheese.

Keywords: CLA; diet; goat cheese; nutrition animal; vegetable oil

\section{Introduction}

The current focus of the market for animal products has been directed toward the search for foods with lower fat contents. Goat milk is associated with positive health outcomes due to its intrinsic properties, such as low allergenic potential, high digestibility and nutritional value [1]. The lipid composition of goat milk determines its nutritional quality because lipid components, particularly fatty acids, are involved in the production and quality of dairy products and directly affect the taste aspects of milk derivatives [2].

The use of vegetable oils into the diets of goats contributes to the search for alternatives to the dairy goat activity, especially in the dry season (August and January), to increase the nutritional enrichment of dairy products [3]. Among the sources of lipids, faveleira (Cnidoscolus quercifolius or phyllacanthus), sesame (Sesamum indicum L.) and castor (Ricinus communis L.) oils have received attention due to their high levels of unsaturated fatty acids [4]; however, the effects of dietary supplementation on small ruminants and the changes in the characteristics of milk and milk products as a result are not well known.

Studies have shown that different milk fat compositions are related to variations in the diets of small ruminants, demonstrating efficiency in increasing the concentration of conjugated linoleic acid (CLA) in milk fat [5,6]. Sanz Sampelayo et al. [7] reported that the lipid metabolism in the mammary gland is directly related to milk production and can induce different responses among species of animals (goats and sheep). Other authors have assessed the fatty acid profile of different types of goat cheese of different races [8], maturation times [9], regions [10] and lactation periods [11]. Among them, monounsaturated and polyunsaturated fatty acids, primarily linoleic acid (C18:2), stand out in dairy products (such as cheeses made with goat milk) for presenting concentrations ranging from $1.94 \%$ to $3.95 \%$ (w/w; Total FAME) $[8,12]$.

Modifications in animal diet can significantly multiply concentrations of bioactive compounds (e.g., CLA and/or omega-3 fatty acids) in milk several times. The most effective strategies involved supplementing ruminant feed with different oils or oilseeds enriched in linoleic or linolenic acids $[7,13,14]$. However the effects of processing conditions, storage, and aging on the CLA content of various types of cheeses are less relevant. Luna et al. [15] employed high temperature conditions in the manufacture of processed cheeses and they found that the production process exerted a negligible effect on the CLA content during manufacture. Although Buccioni et al. [9] reported that the total CLA content in Pecorino cheese rose by more than $10 \%$ during ripening this increases were lower than when animal diet was supplemented with plant oils [16]. 
The increase in the CLA content of foods derived from ruminants has attracted attention, for potentially having positive effects on human health due to the anticarcinogenic properties of this fatty acid [17,18], and the intake of the cis-9,trans-11-CLA isomer in the diet lowers blood cholesterol levels [19]. Given the nutritional benefits of goat milk and its derivatives, the objective of this study was to evaluate the effect of supplementing the diet of dairy goats with faveleira, sesame or castor oils and the influence of this supplementation on the fatty acid profile of cheese.

\section{Results and Discussion}

Supplementation with $4.0 \%$ vegetable oil in diets for lactating goats did not promote an increase in the percentage of total fat in goat milk and cheese ( $p \geq 0.05$, Table 1$)$.

Table 1. Means and standard errors of the fatty acid profile ( $\%$ area $\left.^{1}\right)$ of cheese made with milk from goats fed with different vegetable oils.

\begin{tabular}{|c|c|c|c|c|c|c|}
\hline \multirow{2}{*}{ Fatty acids (\%) } & \multicolumn{4}{|c|}{ Treatments (Cheese) $^{2}$} & \multirow{2}{*}{ SEM } & \multirow{2}{*}{ Significance } \\
\hline & Control Without oil & "Faveleira" oil & Sesame oil & Castor oil & & \\
\hline Total Fat & 23.35 & 24.17 & 22.94 & 22.67 & 0.283 & ns \\
\hline $\mathrm{C} 4: 0$ & 0.06 & 0.00 & 0.03 & 0.15 & 0.027 & ns \\
\hline C6:0 & 0.91 & 0.62 & 0.88 & 0.74 & 0.081 & ns \\
\hline $\mathrm{C} 7: 0$ & 0.02 & 0.02 & 0.02 & 0.02 & 0.001 & $\mathrm{~ns}$ \\
\hline $\mathrm{C} 8: 0$ & 2.15 & 1.88 & 2.07 & 2.02 & 0.048 & $\mathrm{~ns}$ \\
\hline C9:0 & 0.06 & 0.05 & 0.06 & 0.06 & 0.003 & $\mathrm{~ns}$ \\
\hline $\mathrm{C} 10: 0$ & $8.68^{\mathrm{a}}$ & $6.90^{\mathrm{ab}}$ & $6.38^{\mathrm{b}}$ & $8.02^{a b}$ & 0.315 & $*$ \\
\hline C11:0 & 0.09 & 0.08 & 0.08 & 0.09 & 0.004 & ns \\
\hline $\mathrm{C} 12: 0$ & $4.44^{\mathrm{a}}$ & $3.08^{b}$ & $3.28^{\mathrm{b}}$ & $3.73^{\mathrm{ab}}$ & 0.143 & $*$ \\
\hline $\mathrm{C} 13: 0$ & 0.03 & 0.07 & 0.11 & 0.09 & 0.011 & $\mathrm{~ns}$ \\
\hline $\mathrm{C} 14: 0$ & $11.03^{\mathrm{a}}$ & $8.35^{\mathrm{c}}$ & $9.14^{b c}$ & $10.17^{\mathrm{ab}}$ & 0.268 & * \\
\hline $\mathrm{C} 15: 0$ & $0.84^{\mathrm{ab}}$ & $0.67^{\mathrm{c}}$ & $0.72^{\mathrm{bc}}$ & $0.90^{\mathrm{a}}$ & 0.025 & $*$ \\
\hline $\mathrm{C} 16: 0$ & $28.13^{\mathrm{a}}$ & $26.45^{\mathrm{ab}}$ & $24.66^{\mathrm{b}}$ & $27.62^{\mathrm{ab}}$ & 0.485 & $*$ \\
\hline $\mathrm{C} 17: 0$ & 0.56 & 0.42 & 0.43 & 0.56 & 0.016 & $\mathrm{~ns}$ \\
\hline $\mathrm{C} 18: 0$ & $11.88^{\mathrm{b}}$ & $15.13^{\mathrm{a}}$ & $16.64^{\mathrm{a}}$ & $11.63^{\mathrm{b}}$ & 0,607 & $*$ \\
\hline C19:0 & 0.03 & 0.05 & 0.05 & 0.03 & 0.003 & $\mathrm{~ns}$ \\
\hline C20:0 & 0.31 & 0.29 & 0.31 & 0.32 & 0.008 & ns \\
\hline $\mathrm{C} 21: 0$ & 0.02 & 0.02 & 0.04 & 0.04 & 0.035 & ns \\
\hline $\mathrm{C} 22: 0$ & 0.08 & 0.05 & 0.07 & 0.06 & 0.005 & ns \\
\hline $\mathrm{C} 23: 0$ & 0.02 & 0.01 & 0.01 & 0.04 & 0.003 & $\mathrm{~ns}$ \\
\hline $\mathrm{C} 24: 0$ & 0.10 & 0.12 & 0.14 & 0.16 & 0.012 & $\mathrm{~ns}$ \\
\hline $\mathrm{C} 14: 1$ & $0.16^{\mathrm{a}}$ & $0.11^{\mathrm{b}}$ & $0.11^{\mathrm{b}}$ & $0.13^{\mathrm{ab}}$ & 0.007 & $*$ \\
\hline C15:1 & $0.27^{\mathrm{a}}$ & $0.19^{\mathrm{b}}$ & $0.22^{\mathrm{ab}}$ & $0.29^{\mathrm{a}}$ & 0.011 & $*$ \\
\hline C16:1 & $0.74^{\mathrm{ab}}$ & $0.80^{\mathrm{a}}$ & $0.68^{b}$ & $0.83^{a}$ & 0.017 & * \\
\hline $\mathrm{C} 17: 1$ & $0.23^{\mathrm{ab}}$ & $0.18^{\mathrm{b}}$ & $0.18^{b}$ & $0.29^{\mathrm{a}}$ & 0.012 & * \\
\hline $\mathrm{C} 18: 1 \mathrm{n} 11 \mathrm{cis}$ & $0.49^{b}$ & $0.83^{\mathrm{a}}$ & $0.78^{\mathrm{a}}$ & $0.30^{\mathrm{b}}$ & 0.050 & * \\
\hline C18:1 n9cis & $22.70^{a b}$ & $25.61^{\mathrm{a}}$ & $25.70^{\mathrm{a}}$ & $18.88^{b}$ & 0.875 & * \\
\hline C18:1 n9trans & $1.50^{\mathrm{b}}$ & $2.47^{\mathrm{a}}$ & $2.18^{a}$ & $1.05^{b}$ & 0.129 & $*$ \\
\hline $\mathrm{C} 18: 1 \mathrm{n} 9$ cis, $12-\mathrm{OH}$ & $\mathrm{Nd}$ & nd & nd & 6.56 & 0.346 & * \\
\hline
\end{tabular}


Table 1. Cont.

\begin{tabular}{|c|c|c|c|c|c|c|}
\hline \multirow{2}{*}{ Fatty acids (\%) } & \multicolumn{4}{|c|}{ Treatments (Cheese) $^{2}$} & \multirow{2}{*}{ SEM } & \multirow{2}{*}{ Significance } \\
\hline & Control Without oil & "Faveleira" oil & Sesame oil & Castor oil & & \\
\hline $\mathrm{C} 18: 2 \mathrm{n} 6$ cis & $2.77^{\mathrm{b}}$ & $3.48^{\mathrm{a}}$ & $3.35^{\mathrm{a}}$ & $2.57^{b}$ & 0.095 & $*$ \\
\hline C18:2 n6trans & $0.05^{b}$ & $0.06^{\mathrm{a}}$ & $0.06^{\mathrm{ab}}$ & $0.05^{b}$ & 0.003 & $*$ \\
\hline C18:3 n6 & 0.11 & 0.08 & 0.09 & 0.11 & 0.005 & $\mathrm{~ns}$ \\
\hline C18:3 n3 & $0.36^{\mathrm{a}}$ & $0.24^{b}$ & $0.24^{b}$ & $0.25^{\mathrm{b}}$ & 0.012 & $*$ \\
\hline C20:1 n9 & 0.03 & 0.01 & 0.02 & 0.02 & 0.004 & ns \\
\hline $\mathrm{C} 20: 2$ & $0.08^{b}$ & $0.06^{b}$ & $0.06^{b}$ & $0.85^{\mathrm{a}}$ & 0.062 & $*$ \\
\hline C20:3 n6 & 0.05 & 0.03 & 0.06 & 0.04 & 0.005 & ns \\
\hline C20:4 n6 & 0.19 & 0.17 & 0.19 & 0.20 & 0.004 & ns \\
\hline $\mathrm{C} 20: 5 \mathrm{n} 3$ & 0.01 & 0.00 & 0.01 & 0.01 & 0.001 & ns \\
\hline $\mathrm{C} 22: 2$ & 0.26 & 0.29 & 0.22 & 0.29 & 0.015 & ns \\
\hline
\end{tabular}

${ }^{1}$ Identified by comparing the retention times of methyl esters of samples with those of standards and were quantified by normalising the areas of methyl esters and expressed as a percentage of area (\%); ${ }^{2} 0 \%$ oil (control); 4.0\% "Faveleira" oil; 4.0\% Sesame oil; 4.0\% Castor oil. SEM = standard error of the mean. * $p<0.05$; ns - non significant; nd - non detected; ${ }^{a}$ Means followed by different lowercase letters in the same row indicate significant differences with Tukey's test at the 5\% significance level.

Thirty-eight fatty acids were identified in the fatty acid profile of goat cheese: 20 saturated fatty acids (SFA), nine monounsaturated fatty acids (MUFA), and nine polyunsaturated fatty acids (PUFA). Among the fatty acids identified, eight constituted $91 \%$ of the total areas of the chromatograms: C8:0, C10:0, C12:0, C14:0, C16:0, C18:0, C18:1 and C18:2. Oleic acid (C18:1 n9cis) was the fatty acid that contributed most to the profile of unsaturated fatty acids in cheese, and palmitic acid (C16:0) contributed most to the profile of saturated fatty acids.

\subsection{Fatty Acid Profile}

There was a significant difference $(p<0.05)$ in the fatty acids percentage of C10:0, C12:0, C14:0 and C16:0, revealing a downward trend in the percentage of these fatty acids in cheese from goats treated with faveleira and sesame oils in relation to cheese from the control animals. However, cheeses with castor oil had intermediate values for these fatty acids compared to those with the other added oils and to the control with no addition of oil.

The inclusion of vegetable oils in the diet caused a significant increase $(p<0.05)$ in the concentration of stearic acid (C18:0) in cheeses, which increased from $11.88 \%$ in the control to an average percentage of $16.64 \%$ after treatment with sesame oil and $15.13 \%$ with faveleira oil; however, there were no differences in the values $(p \geq 0.05)$ between the castor oil treatment and the control. The increase in the stearic acid concentration can be attributed to extensive ruminal biohydrogenation of the fatty acids $\mathrm{C} 18: 3, \mathrm{C} 18: 2$ and $\mathrm{C} 18: 1$ because together, they represent approximately 85 and $67 \%$ of the fatty acids of sesame and faveleira oils, respectively [4], wherein the final step of rumen biohydrogenation of linoleic acid is the hydrogenation of acid C18:1 trans-11 to C18:0 [20]. This outcome seems to be positive, as part of stearic acid will be transformed into oleic acid by the action of $\Delta-9$ desaturase enzyme in the mammary gland, which promotes the unsaturation of stearic acid (18:0) at carbon 9, producing the oleic acid (C18:1 n9cis) present in the final product [21]. 
The lowest percentage of stearic acid was detected in cheese with castor oil, most likely a result of the strong stability of hydroxyricinoleic acid $(\mathrm{C} 18: 1 \mathrm{n} 9 \mathrm{cis}, 12-\mathrm{OH})$, present in large amounts in only this oil and hindered the hydrolysis of other fatty acids in the rumen, leading to the formation of hydrogen bonds with the hydroxyl group present in the ricinoleic acid [22]. Consequently, a higher concentration of ricinoleic acid was present in the mammary gland and in the goat cheese, which had percentages of ricinoleic acid greater than $6 \%$ and a lower percentage of oleic acid (C18:1 n9cis) compared to the other oil treatment groups. Another factor that can be attributed to the reduced amount of stearic acid in cheese made from milk from goats supplemented with castor oil is the low concentration of linoleic acid in castor oil [4].

Another aspect that corroborates the influence of ricinoleic acid in the conversion of vaccenic acid (C18:1 trans-11) to stearic $(\mathrm{C} 18: 0)$ is the fact that unsaturated fatty acids can alter the rumen fermentation of fibre by their toxic action on fibrolytic bacteria, which are involved in the biohydrogenation of polyunsaturated fatty acids [23]. Medeiros et al. [4] reported that among the three oils studied here, castor oil showed the highest percentage of unsaturated fatty acids, $71 \%$ of which are due to the presence of ricinoleic acid in this oil.

The content of linoleic acid (C18:2) was significant $(p<0.05)$ in cheeses with faveleira $(3.48 \%)$ and sesame oils (3.35\%), indicating a good production of biohydrogenation intermediates [6]. Increased levels of linolenic acid (C18:3) in dairy products are not usual because these levels require that fatty acids coming from the diet are protected from ruminal biohydrogenation [24]. In the present study, there was a decrease $(p<0.05)$ in $\mathrm{C} 18: 3 \mathrm{n} 3$ in the three treatments with vegetable oils compared to the control. Polyunsaturated fatty acids present in the rumen suffer less biohydrogenation because goats have a greater salivary secretion rate and consequently greater capacity to protect polyunsaturated fatty acids due to the higher rumen $\mathrm{pH}$ stability as a function of the buffering characteristic of saliva [5,11].

\subsection{CLA Isomers in the Fat of Cheeses}

Table 2 shows an increase $(p<0.05)$ in the levels of CLA isomers in the fat of cheeses, particularly due to the increase in C18:2 cis-9,trans-11, which almost doubled its value in treatments with faveleira (1.07) and sesame oils (0.89) compared to the control cheese (0.56) and the cheese from goats fed castor oil (0.55). The other CLA isomers were found only in trace amounts; thus, it can be inferred that with a regular diet, this isomer is poorly produced in the rumen of goats [25].

Cheeses in this study may have had an increased percentage of cis-9,trans-11-CLA due to the supplementation of animal diets with vegetable oils rich in C18:2, such as faveleira and sesame oils, these cheeses were not matured, only stored for seven days, which possibly did not contribute to this increase.

The changes observed in the cis-9,trans-11-CLA content are in agreement with the results of Santos et al. [12], who studied caprine Coalho cheese enriched with CLA by dietary supplementation of goats with soybean oil and observed a percentage of CLA that was 3 times higher than that in the control cheese. This isomer represents up to $90 \%$ of the total CLA of milk fat, and the results confirmed some preliminary studies carried out by Bouattour et al. [26] and Bernard et al. [5], in which the inclusion of vegetable oils in the diet of goats provided an increase over $100 \%(\mathrm{w} / \mathrm{w})$ in the CLA levels in the goat 
milk. This information reinforces a rational approach to improve the CLA levels in milk fat with increased dietary intake of unsaturated fatty acids, which are substrates for the synthesis of ruminal CLA [14,27]. Beside, Luna et al. [15] emphasizes that the CLA content of processed cheese did not modify the isomer profile in these dairy products, thereby confirming the stability of rumenic acid during manufacturing.

Table 2. Average $\left(\operatorname{area} \%{ }^{1}\right)$ and relationships between saturated (SFA), monounsaturated (MUFA), polyunsaturated (PUFA) fatty acids and CLA of cheeses made with milk from goats fed with different vegetable oils.

\begin{tabular}{|c|c|c|c|c|c|c|}
\hline \multirow[b]{2}{*}{ Fatty acids (\%) } & \multicolumn{4}{|c|}{ Treatments (Cheese) $^{2}$} & \multirow[b]{2}{*}{ SEM } & \multirow[b]{2}{*}{ Significance } \\
\hline & $\begin{array}{c}\text { Control } \\
\text { Without oil } \\
\end{array}$ & $\begin{array}{c}\text { "Faveleira" } \\
\text { oil } \\
\end{array}$ & Sesame oil & $\begin{array}{c}\text { Castor } \\
\text { oil } \\
\end{array}$ & & \\
\hline CLA $^{3}-\mathrm{C} 18: 2$ cis-9, trans-11trans-11 & $0.56^{b}$ & $1.07^{\mathrm{a}}$ & $0.89^{\mathrm{a}}$ & $0.55^{\mathrm{b}}$ & 0.055 & * \\
\hline CLA-C18:2 cis-9, cis-11 & $0.01^{\mathrm{c}}$ & $0.03^{\mathrm{a}}$ & $0.02^{\mathrm{ab}}$ & $0.01^{\mathrm{bc}}$ & 0.002 & $*$ \\
\hline CLA-C18:2 trans -9, trans -11 & $0.01^{\mathrm{b}}$ & $0.01^{\mathrm{b}}$ & $0.01^{\mathrm{b}}$ & $0.06^{\mathrm{a}}$ & 0.005 & $*$ \\
\hline CLA-C18:2 trans- 9 , cis-11 & $0.01^{\mathrm{b}}$ & $0.01^{\mathrm{b}}$ & $0.01^{\mathrm{b}}$ & $0.12^{\mathrm{a}}$ & 0.016 & * \\
\hline SCFA short chain fatty acids ${ }^{4}$ & 3.19 & 2.58 & 3.07 & 3.00 & 0.139 & ns \\
\hline MCFA medium chain fatty ${ }^{4}$ acids ${ }^{4}$ & $25.55^{\mathrm{a}}$ & $19.44^{b}$ & $20.05^{b}$ & $23.42^{\mathrm{ab}}$ & 0.670 & $*$ \\
\hline LCFA long chain fatty ${ }^{4}$ acids ${ }^{4}$ & $71.26^{\mathrm{b}}$ & $77.98^{a}$ & $76.88^{a}$ & $73.57^{\mathrm{ab}}$ & 0.725 & $*$ \\
\hline SFA saturated fatty acids & 69.46 & 64.27 & 64.93 & 66.40 & 0.801 & ns \\
\hline MUFA monounsaturated fatty acids & 26.11 & 30.20 & 29.87 & 28.35 & 0.813 & ns \\
\hline PUFA polyunsaturated fatty acids & $4.43^{b}$ & $5.53^{\mathrm{a}}$ & $5.21^{\mathrm{a}}$ & $5.19^{\mathrm{a}}$ & 0.115 & * \\
\hline PUFA:SFA & $0.06^{\mathrm{c}}$ & $0.09^{\mathrm{a}}$ & $0.08^{\mathrm{ab}}$ & $0.08^{b}$ & 0.002 & $*$ \\
\hline MUFA:SFA & 0.38 & 0.47 & 0.46 & 0.44 & 0.016 & ns \\
\hline DFA $^{5}$ & $42.43^{c}$ & $50.86^{\mathrm{a}}$ & $51.51^{\mathrm{a}}$ & $45.16^{b}$ & 1.169 & $*$ \\
\hline IA $^{6}$ & 2.55 & 1.76 & 1.85 & 2.33 & 0.125 & ns \\
\hline$(\mathrm{C} 18: 0+\mathrm{C} 18: 1) / \mathrm{C} 16: 0$ & $1.31^{\mathrm{b}}$ & $1.67^{\mathrm{ab}}$ & $1.87^{\mathrm{a}}$ & $1.21^{\mathrm{b}}$ & 0.073 & $*$ \\
\hline
\end{tabular}

${ }^{1}$ Identified by comparing the retention times of methyl esters of samples with those of standards and were quantified by normalising the areas of methyl esters and expressed as a percentage of area (\%); ${ }^{2} 0 \%$ oil (control); 4.0\% "Faveleira" oil; 4.0\% Sesame oil; 4.0\% Castor oil; ${ }^{3}$ CLA = Conjugated linoleic acid; ${ }^{4}$ SCFA $=\left(\right.$ C4:0-C:9:0); MCFA (C10:0-C15:1); LCFA (C16:0-C24:0). Prandini et al. [8]; ${ }^{5}$ Desirable Fatty Acids $=$ MUFA+PUFA+C18:0. ${ }^{6}$ Atherogenicity index $=[(\mathrm{C} 12: 0+(4 \times \mathrm{C} 14: 0)+\mathrm{C} 16: 0)] /$ MUFA + PUFA. $\mathrm{SEM}=$ standard error of the mean. $* p<0.05$; ns —non significant. ${ }^{\mathrm{a}, \mathrm{b}, \mathrm{c}}$ Means followed by different lowercase letters in the same row indicate significant differences with Tukey's test at the $5 \%$ significance level.

Despite these changes observed in the fatty acid profile, Medeiros et al. [28] emphasize that in general, the addition of different oils (faveleira, sesame or castor oils) to the diets of dairy goats did not promote changes in the sensory quality of the cheese produced and can be used as a dietary supplement.

\subsection{Relationships between Fatty Acids}

The addition of vegetable oils had no effect $(p \geq 0.05)$ on the percentage of short-chain fatty acids (C4 to C9), which could lead to changes in the sensory quality of cheese, because these fatty acids are responsible for relevant aromatic changes in milk and thus in cheese [29]. When pronounced, the "goat" flavour is one of the factors for refusal of dairy products; however, substances responsible for 
goat flavour are not well known [2]. Silanikove et al. [30] reported that the characteristics of goat milk flavour can be attributed to the presence of lipids in the form of short-chain fatty acids, mainly caproic (C6:0) and caprylic acids (C8:0).

Significant differences $(p<0.05)$ were observed in the decrease in total medium-chain fatty acids (MCFA), which represents the sum of C10:0 and C15:1 [8] in cheeses from goats supplemented with faveleira or sesame oil compared to control cheese. This change indicates that the addition of dietary lipids, which are derived from de novo synthesis, interfered with ruminal activity [16]. These results corroborate those by Santos et al. [31], who supplemented the diet of lactating cows with soybean oil and whole milled grain and found a reduction in medium-chain fatty acids, especially with the addition of oil in the free form, as used in this experiment. The synthesis of these fatty acids occurs in the mammary gland, with the participation of the enzymes acetyl CoA carboxylase and fatty acid synthetase, which use acetate as the main lipogenic precursor in ruminants [32]. Fernandes et al. [3] studied the milk profile of Moxotó crossbred goats fed diets supplemented with sunflower and cotton oils and reported that adding oil to the diet decreased the amount of medium-chain fatty acids, such as myristic acid (C14:0).

A significant increase $(p<0.05)$ was observed in the levels of polyunsaturated fatty acids (PUFA) and long-chain fatty acids (LCFA) in cheeses made with milk from goats fed with faveleira, sesame or castor oil. The increase in the fatty acids C18:0, C18:1 n9cis, C18:1 n9trans, and C18:2 n6cis after treatments with sesame and faveleira oils contributed to the increase in the LCFA percentage, which was $78 \%$ for faveleira oil and $77 \%$ for sesame oil compared to control cheese with only $71 \%$ of the total long-chain fatty acids. This result may be due to the biohydrogenation process that occurs from the rumen up to the mammary gland of goats [7]. For cheese made from milk from goats supplemented with castor oil, this increase in the LCFA profile was lower compared to other oil treatments due to the lower percentage of stearic and oleic acids; the PUFA percentage remained similar due to the considerable presence of $6.5 \%$ of ricinoleic acid $(p<0.05)$.

The fatty acid profile of the diet is the main factor of nutritional importance that modifies the content of long-chain fatty acids in milk [14,23]. Authors have shown that medium- and long-term supplementation with lipid sources rich in C18:2 [33] and C18:3 [13] modified the fatty acid profile of goat milk. Pereira et al. [6] studied the fatty acid profile of milk from goats supplemented with castor and licuri oils and confirmed the increase in long-chain fatty acids seen with this experiment. Additionally, these authors reported that the inclusion of castor oil has the advantage of increasing polyunsaturated fatty acids, which are beneficial to human health; however, these fatty acids also accentuate the rancid flavour characteristic of goat milk.

The use of vegetable oils at $4 \%$ in the diet of goats resulted in an increase $(p<0.05)$ in the DFA level (Table 2), especially due to the addition of sesame $(51.51 \%)$ or faveleira oil $(50.86 \%)$, followed by treatment with castor oil $(45.16 \%)$, compared to control cheese $(42.43 \%)$. The results for the AI were not significant $(p \geq 0.05)$ between the cheeses analyzed, while the relationship (C18:0+ C18:1/C16:0) effect was observed $(p<0.05)$, showing higher values for the treatments with cheese faveleira and sesame. The intake of monounsaturated fatty acids provides benefits for human health by causing a decrease in total cholesterol levels in blood plasma [34]; for this reason, the presence of these fatty acids is desirable in the diet, represented here with a better percentage in the cheeses from the milk of goats supplemented with sesame or faveleira oil. 


\section{Experimental}

\subsection{Cheese Samples and Production Technology}

The cheese was made from the milk of crossbred Saanen $\times$ French Alpine goats, which were hand milked, kept in confinement and fed diets prepared according to NRC [35] requirements (Table 3).

Table 3. Percentage and chemical composition of experimental diets.

\begin{tabular}{|c|c|c|c|c|}
\hline \multirow{3}{*}{ Components } & \multicolumn{4}{|c|}{ Experimental diets } \\
\hline & Control Without oil & "Faveleira" Oil & Sesame Oil & Castor oil \\
\hline & \multicolumn{4}{|c|}{ Proportion of ingredients (\% Dry matter) } \\
\hline Tifton hay & 49.30 & 49.06 & 49.06 & 49.06 \\
\hline Ground corn & 37.29 & 32.99 & 32.99 & 32.99 \\
\hline Soybean meal & 10.79 & 11.34 & 11.34 & 11.34 \\
\hline Faveleira oil & 0.00 & 4.00 & 0.00 & 0.00 \\
\hline Sesame oil & 0.00 & 0.00 & 4.00 & 0.00 \\
\hline Castor oil & 0.00 & 0.00 & 0.00 & 4.00 \\
\hline Core mineral ${ }^{1}$ & 1.37 & 1.47 & 1.47 & 1.47 \\
\hline \multirow[t]{2}{*}{ Limestone } & 1.25 & 1.13 & 1.13 & 1.13 \\
\hline & \multicolumn{4}{|c|}{ Chemical composition (\%) } \\
\hline Dry matter $^{2}$ & 86.99 & 87.42 & 87.42 & 87.42 \\
\hline Organic matter & 91.91 & 91.96 & 91.96 & 91.96 \\
\hline Mineral matter & 8.09 & 8.04 & 8.04 & 8.04 \\
\hline Crude protein & 13.82 & 13.69 & 13.69 & 13.69 \\
\hline Ether extract & 3.15 & 6.97 & 6.97 & 6.97 \\
\hline Neutral detergent fiber ${ }^{3}$ & 39.92 & 39.19 & 39.19 & 39.19 \\
\hline Acid detergent fiber ${ }^{3}$ & 18.70 & 18.48 & 18.48 & 18.48 \\
\hline Lignin & 3.12 & 3.03 & 3.03 & 3.03 \\
\hline Total carbohydrates & 74.95 & 71.31 & 71.31 & 71.31 \\
\hline Total digestible nutrients & 61.61 & 69.68 & 69.05 & 69.19 \\
\hline Metabolizable energy (Mcal/kg) ${ }^{4}$ & 2.36 & 2.64 & 2.67 & 2.60 \\
\hline
\end{tabular}

${ }^{1}$ Mineral supplement (nutrients $/ \mathrm{kg}$ de supplement): $\mathrm{Ca}=210 \mathrm{~g} ; \mathrm{P}=70 \mathrm{~g} ; \mathrm{Mg}=5 \mathrm{~g} ; \mathrm{F}=700.00 \mathrm{mg}$; $\mathrm{Zn}=3.010 \mathrm{mg} ; \mathrm{Cu}=440 \mathrm{mg} ; \mathrm{Mn}=1,485 \mathrm{mg} ; \mathrm{Co}=25 \mathrm{mg} ; \mathrm{Fe}=340 \mathrm{mg} ; \mathrm{Cr}=6.00 \mathrm{mg} ; \mathrm{Se}=20 \mathrm{mg} ; \mathrm{I}=48 \mathrm{mg}$; $\mathrm{S}=10 \mathrm{~g}$; Vit. A $=250,000.00 \mathrm{UI} / \mathrm{kg}$; Vit. D3 $=40,000.00 \mathrm{UI} / \mathrm{kg}$; Vit $\mathrm{E}=350.00 \mathrm{UI} / \mathrm{kg} .{ }^{2} \%$ on the basis dry matter; ${ }^{3}$ Free ash and protein; ${ }^{4} \mathrm{EM}(\mathrm{Mcal} / \mathrm{kg})=\mathrm{ED}(\mathrm{Mcal} / \mathrm{kg}) \times 0.86$.

There were four diets used in the study: 1 - basal diet without the addition of vegetable oil to the dry matter, 2-basal diet plus 4\% faveleira oil, 3-basal diet plus 4\% sesame oil, and 4-basal diet plus $4 \%$ castor oil. The seeds of faveleira stand out due to the presence of unsaturated fatty acids, especially linoleic acid (C18:2 n6 cis), which accounts for $63.8 \%$ of the linoleic acid. Castor seeds show $71.8 \%$ ricinoleic acid $(\mathrm{C} 18: 1$ cis-9,12-OH) and sesame seeds produce oil rich in unsaturated fatty acids (48.1\% of linoleic acid and $36.5 \%$ of oleic acid) [4].

The trial lasted 76 days and followed a Latin square design $(4 \times 4)$, with four treatments and four processing periods. In each period, the cheeses were made using $10 \mathrm{~L}$ of goat milk per treatment. The milk samples were pasteurised at $65{ }^{\circ} \mathrm{C}\left( \pm 1{ }^{\circ} \mathrm{C}\right)$ for 30 min followed by cooling to $37{ }^{\circ} \mathrm{C}\left( \pm 2{ }^{\circ} \mathrm{C}\right)$ and coagulation with the following additives in this sequence: $0.25 \mathrm{~mL} / \mathrm{L} 85 \%$ lactic acid solution, $0.1 \mathrm{~g} / \mathrm{L}$ lyophilised lactic starter culture with Lactococcus lactis subsp. cremoris and Lactococcus lactis subsp. lactis (R-704, Christian Hansen Ind. \& Com. Ltd., Valinhos, SP, Brazil), $0.5 \mathrm{~mL} / \mathrm{L} 50 \%$ calcium chloride, and $0.9 \mathrm{~mL} / \mathrm{L}$ commercial coagulant (Ha-La ${ }^{\circledR}$, Christian Hansen Ind. \& Com. Ltd.). After 
40 min of rest, the curd was gently cut into cubes, drained, and salted in brine $(9 \mathrm{~g} / \mathrm{L} \mathrm{NaCl})$. Then, the cheese mass was distributed into $250 \mathrm{~g}$ perforated moulds, pressed for $4-6 \mathrm{~h}$ at room temperature, vacuum packed and stored under refrigeration $4 \pm 1{ }^{\circ} \mathrm{C}$ for 7 days. After this period, the fatty acid profile was analysed.

\subsection{Analysis of the Fatty Acids Profile of Goat Cheese}

The determination of the fatty acids profile in the goat cheese started with the extraction of total fat, according to the procedure described by Folch, Lees and Stanley [36], followed by saponification and esterification steps [37].

The fatty acid profile of esterified cheese samples was determined in a gas chromatograph Varian 430-GC with a flame ionisation detector (FID) and fused silica capillary column (CP WAX 52 CB Varian), with dimensions of $60 \mathrm{~m} \times 0.25 \mathrm{~mm} \times 0.25 \mathrm{~mm}$ film thickness. Helium was used as the carrier gas (flow rate of $1 \mathrm{~mL} / \mathrm{min}$ ). The oven temperature started at $100{ }^{\circ} \mathrm{C}$ and was programmed to increase by $2.5^{\circ} \mathrm{C} / \mathrm{min}$ to reach a final temperature of $240{ }^{\circ} \mathrm{C}$ and then maintain that temperature for 20 min for a total of $76 \mathrm{~min}$. The injector temperature was maintained at $250{ }^{\circ} \mathrm{C}$ and the detector temperature at $260{ }^{\circ} \mathrm{C}$. An aliquot of $1.0 \mu \mathrm{L}$ of the esterified extract was injected into a split/splitless injector.

The chromatograms were recorded on Galaxie Chromatography Data System software. Fatty acids were identified by comparing the retention times of methyl esters of samples with those of standards from a Supelco ME19-Kit (Fatty Acid methyl Esters C6-C24) and with CLA (cis/trans linoleic acid methyl ester mix). The results were quantified by normalising the areas of methyl esters and expressed as a percentage of area $(\%)$.

The relationships PUFA/SFA, MUFA/SFA, $(\mathrm{C} 18: 0+\mathrm{C} 18: 1) / \mathrm{C} 16: 0$, the atherogenicity index (AI) were calculated according to Ulbright and Southgate [38], and the percentage of desirable fatty acids (DFA), expressed as the sum of unsaturated fatty acids plus stearic acid [39].

\subsection{Statistical Analysis}

A simultaneous double Latin square $(4 \times 4)$ experimental design was used, with 8 animals randomly distributed into 4 treatments and 4 periods. The statistical model used in the analysis of the fatty acid data was the following:

$$
Y i j k l=\mu+Q i+T j+P k+A(i) l+Q T i j+\xi i j k
$$

where $Y i j k l$ is the observation of goat $j$ in period $k$ submitted to treatment $i$, with $i, j$, and $k=1,2,3$, or $4 ; \mu$ is the general effect of the mean; $Q i$ is the effect of the Latin square $(Q=1,2) ; T i$ is the effect of treatment $i$, with $i=1,2,3$, or $4 ; P k$ is the effect of period $k$; $A$ is the effect of goat $l$ in square $i$, with $l=1,2,3$, or 4 ; $Q T$ is the interaction of the effect of Latin square $i$ with treatment $j$; and $\xi i j k$ is the random error associated with each observation Yijkl. Treatment means were compared by Tukey's test at $5 \%$ error probability using statistical software [40].

\section{Conclusions}

Lipid supplementation with faveleira, sesame or castor oil in the diet of dairy goats did not change the total fat content of cheeses; however, supplementation promoted a decrease in the percentage of 
saturated fatty acids C12:0, C14:0 and C16:0 and an increase in the percentage of PUFA and LCFA. The use of sesame and faveleira oils caused an increase in the DFA, oleic acids, linoleic acid and cis-9, trans-11-CLA profiles in goat cheese, indicating that utilization the diet of these goats can be a way of controlling the physicochemical characteristics of milk and consequently its derivatives, such as cheese.

\section{Acknowledgments}

The authors are grateful to $\mathrm{CNPq}$ (Conselho Nacional de Desenvolvimento Científico e Tecnológico-Brazil) and MAPA (Ministério da Agricultura, Pecuária e Abastecimento-Brazil) for financial support (Edital MAPA - Process 578403/2008-0 e 578217/2008-2).

\section{Author Contributions}

Ertha Medeiros contributed in the data obtaining, analysis and interpretation and in the manuscript writing. Rita Queiroga contributed in the data analysis and interpretation and also in the manuscript writing. Maria Oliveira contributed in the execution and interpretation of analysis. Ariosvaldo Medeiros and Mayara Sabedot contributed in the execution of field tests and interpretation of analysis, Marco Bomfim contributed to the study design and data analysis. Marta Madruga contributed to the study design, data analysis and manuscript writing.

\section{Conflicts of Interest}

The authors declare no conflict of interest.

\section{References}

1. Raynal-Ljutovac, K.; Lagriffoul, G.; Paccard, P.; Guillet, I.; Chilliard, Y. Composition of goat and sheep milk products: an update. Small Rum. Res. 2008, 79, 57-72.

2. Delacroix-Buchet, A.; Lamberet, G. Sensorial properties and typicity of goat dairy products. In Proceedings of the International Conference on Goats, Tour, France, 31 September 2000; pp. 559-563.

3. Fernandes, M.F.; Queiroga, R.C.R.E.; Medeiros, A.N.; Costa, R.G.M.; Bomfim, A.D.; Braga, A.A. Physico-chemical characteristics and fatty acid profile of milk of crossbred Moxotó goats supplemented with cottonseed or sunflower oil. Rev. Bras. Zootec. 2008, 37, 703-710.

4. Medeiros, E.J.L.; Queiroga, R.C.R.E.; Souza, A.G.; Cordeiro, A.M.T.M.; Medeiros, A.N.; Souza, D.L.; Madruga, M.S. Thermal and quality evaluation of vegetable oils used in ruminant feed. J. Therm. Anal. Calorim. 2013, 112, 1515-1521.

5. Bernard, L.; Shingfield, K.J.; Rouel, J.; Ferlay, A.; Chilliard, Y. Effect of plant oils in the diet on performance and milk fatty acid composition in goats fed diets based on grass hay or maize silage. Br. J. Nutr. 2009, 101, 213-224.

6. Pereira, R.A.G.; Oliveira, C.J.B.; Medeiros, A.N.; Costa, R.G.; Bomfim, M.A.D.; Queiroga, R.C.R.E. Physicochemical and sensory characteristics of milk from goats supplemented with castor or licuri oil. J. Dairy Sci. 2010, 93, 456-462.

7. Sanz Sampelayo, M.R.; Chilliard, Y.; Schmidely, P.; Boza, J. Influence of type of diet on the fat constituents of goat and sheep milk. Small Rum. Res. 2007, 68, 42-63. 
8. Prandini, A.; Sigolo, S.; Piva, G. A comparative study of fatty acid composition and CLA concentration in commercial cheeses. J. Food Compos. Anal. 2011, 24, 55-61.

9. Buccioni, A.; Rapaccini, S.; Antongiovanni, M.; Minieri, S.; Conte, G.; Mele, M. Conjugated linoleic acid and C18:1 isomers content in milk fat of sheep and their transfer to Pecorino Toscano cheese. Intern. Dairy J. 2010, 20, 190-194.

10. Luna, P.; Juarez, M.; de la Fuente, M.A. Conjugated linoleic acid content and isomer distribution during ripening in three varieties of cheeses protected with designation of origin. Food Chem. 2007, 103, 1465-1472.

11. Ribeiro, C.V.D.M.; Oliveira, D.E.; Juchem, S.O.; Silva, T.M.; Nalério, E.S. Fatty acid profile of meat and Milk from small ruminants: A review. Rev. Bras. Zootec. 2011, 40, 121-137.

12. Santos, K.M.O.; Bomfim, M.A.D.; Vieira, A.D.S.; Benevides, S.D.; Saad, S.M.I.; Buriti, F.C.A.; Egito, A.S. Probiotic caprine Coalho cheese naturally enriched in conjugated linoleic acid as a vehicle for Lactobacillus acidophilus and beneficial fatty acids. Intern. Dairy J. 2012, 24, 107-112.

13. Nudda, A.; Battacone, G.; Usai, M.G.; Fancellu, S.; Pulina, G. Supplementation with extruded linseed cake affects concentrations of conjugated linoleic acid and vaccenic acid in goat milk. J. Dairy Sci. 2006, 89, 277-282.

14. Luna, P.; Bach, A.; Juárez, M.; de la Fuente, M.A. Influence of diets rich in flax seed and sunflower oil on the fatty acid composition of ewes' milk fat especially on the level of conjugated linoleic acid, n-3 and n-6 fatty acids. Intern. Dairy J. 2008, 18, 99-107.

15. Luna, P.; de la Fuente, M.A.; Juarez, M. Conjugated linoleic acid in processed cheeses during the manufacturing stages. J. Agric. Food Chem. 2005, 53, 2690-2695.

16. Shingfield, K.J.; Chilliard, Y.; Toivonen, V.; Kairenius, P. Trans fatty acids and bioactive lipids in ruminant milk. Adv. Exp. Med. Biol. 2008, 606, 3-65.

17. Pariza, M.W.; Park, Y.; Cook, M.E. The biologically active isomers of conjugated linoleic acid. Prog. Lipid Res. 2001, 40, 283-298.

18. Williams, C.M. Dietary fatty acids and human health. Ann. Zootech. 2000, 49, 165-180.

19. Tricon, S.; Burdge, G.C.; Kew, S.; Banerjee, T.; Russell, J.J.; Jones, E.L.; Grimble, R.F.; William, C.M.; Yaqoob, P.; Calder, P.C. Opposing effects of cis-9, trans-11 and trans-10, cis-12 conjugated linoleic acid on blood lipids in healthy humans. Am. J. Clin. Nutr. 2004, 80, 614-620.

20. Corl, B.A.; Baumgard, L.H.; Dwyer, D.A.; Griinari, J.M.; Phillips, B.S.; Bauman, D.E. The role of $\Delta^{9}$-desaturase in the production of cis-9, trans-11 CLA. J. Nutr. Biochem. 2001, 12, 622-630.

21. Maia, F.J.; Branco, A.F.; Mouro, G.F.; Coneglian, S.M.; Santos, G.T.; Minella, T.F.; Guimarães, K.C. Feeding vegetable oil to lactating goats: milk production and composition and milk fatty acids profile. Rev. Bras. Zootec. 2006, 35, 1504-1513.

22. Conceição, M.M.; Dantas, M.B.; Rosenhaim, R.; Fernandes, V.J., Jr.; Santos, I.M.G.; Souza, A.G. Evaluation of the oxidative induction time of the ethylic castor biodiesel. J. Therm. Anal. Calorim. 2009, 97, 643-646.

23. Nudda, A.; Palmquist, D.L.; Battacone, G.; Fancellu, S.; Rassu, S.P.G.; Pulina, G. Relationships between the contents of vaccenic acid, CLA and $n-3$ fatty acids of goat milk and the muscle of their suckling kids. Livest. Sci. 2008, 118, 195-203.

24. Palmquist, D.L.; Griinari, J.M. Milk fatty acid composition in response to reciprocal combinations of sunflower and fish oils in the diet. Anim. Feed Sci. Techn. 2006, 131, 358-369. 
25. Antongiovanni, M.; Mele, M.; Buccioni, A.; Petacchi, F.; Serra, A.; Melis, M.P.; Cordeddu, L.; Banni, S.; Secchiari, P. Effect of forage/concentrate ratio and oil supplementation on C18:1 and CLA isomers in milk fat from Sarda Ewes. J. Anim. Feed Sci. 2004, 13, 669-672.

26. Bouattour, M.A.; Casals, R.; Albanell, E.; Such, X.; Caja, G. Feeding soybean oil to dairy goats increases conjugated linoleic acid in milk. J. Dairy Sci. 2008, 91, 2399-2407.

27. Gomez-Cortes, P.; Frutos, P.; Mantecon, A.R. Milk production, conjugated linoleic acid content, and in vitro ruminal fermentation in response to high levels of soybean oil in dairy ewe diet. J. Dairy Sci. 2008, 91, 1560-1569.

28. Medeiros, E.J.A.; Queiroga, R.C.R.E; Medeiros, A.N.; Batista, A.S.M.; Félex, S.S.S.; Madruga, M.S. Sensory profile and physicochemical parameters of cheese from dairy goats fed vegetable oils in the semiarid region of Brazil. Small Rum. Res. 2013, 113, 211-218.

29. Haenlein, G.F.W. Goat milk in human nutrition. Small Rum. Res. 2004, 51, 155-163.

30. Silanikove, N.; Leitner, G.; Merin, U.; Prosser, C.G. Recent advances in exploting goats milk: Quality, safety and production aspects. Small Rum. Res. 2010, 89, 110-124.

31. Santos, F.L.; Silva, M.T.C.; Lana, R.P.; Brandão, S.C.C.; Vargas, L.H.; Abreu, L.R. Efeito da suplementação de lipídios na ração sobre a produção de ácidos graxos linoléico conjugado (CLA) e a composição da gordura do leite de vaca. Rev. Bras. Zootec. 2001, 30, 1931-1938.

32. Piperova, L.S.; Teter, B.B.; Bruckental, I. Mammary lipogenic enzyme activity, trans fatty acids and conjugated linoleic acids are altered in lactating dairy cows fed a milk fat depressing diet. J. Nutr. 2000, 130, 2568-2574.

33. Chilliard, Y.; Ferlay, A.; Rouel, J.; Lamberet, G. A review of nutritional and physiological factors affecting goat milk lipid synthesis and lipolysis. J. Dairy Sci. 2003, 86, 1751-1770.

34. Department of Health. Nutritional Aspects of Cardiovascular Disease: Report on Health and Social Subjects. (46); HMSO: London, UK, 1994.

35. National Research Council. Nutrient Requirement of Small Ruminants: Sheep, Goats, Cervids, and New World Camelids; National Academic: Washington, DC, USA, 2007; p. 384.

36. Folch, J.; Lees, M.; Stanley, G.H.S. A simple method for isolation and purification of total lipids from animal tissues. J. Biol. Chem. 1957, 226, 497-509.

37. Hartman, L.; Lago, R.C.A. Rapid preparation of fatty acids methyl esters from lipids. Lab. Pract. 1986, 22, 475-476.

38. Ulbricht, T.L.V.; Southgate, D.A.T. Coronary heart disease: Seven dietary factors. Lancet 1991, 338, 985-992.

39. Banskalieva, V.; Sahlu, T.; Goetsch, A.L. Fatty acid composition of goat muscles and fat depots: A review. Small Rum. Res. 2000, 37, 255-268.

40. SAS. SAS/STAT User's Guide: Statistics, Eletronic version 6.2; SAS Institute: Cary, NC, USA, 1996.

Sample Availability: Not available.

(C) 2014 by the authors; licensee MDPI, Basel, Switzerland. This article is an open access article distributed under the terms and conditions of the Creative Commons Attribution license (http://creativecommons.org/licenses/by/3.0/). 